\title{
Variations of Demonstration Learning Model in Expressing Images in Detail Using Direct Practice Method in Early Childhood
}

\author{
Darmiyati ${ }^{1}$, Sri Rezeki Amalia ${ }^{2 *}$ \\ ${ }^{\mathrm{I} G r a d u a t e}$ Program of Early Childhood Education, Universitas Lambung Mangkurat, Banjarmasin, Indonesia \\ ${ }^{2}$ Department of Early Childhood Education, Universitas Lambung Mangkurat, Banjarmasin, Indonesia.
}

\begin{tabular}{|c|c|}
\hline ARTICLE INFO & A B STRACT \\
\hline \multirow[t]{2}{*}{$\begin{array}{l}\text { Received: 09-03-2017 } \\
\text { Revised: 08-05-2017 } \\
\text { Accepted: 07-06-2017 } \\
\text { Keywords: } \\
\text { Fine motor, drawing in } \\
\text { detail, demonstration, } \\
\text { example non-example, } \\
\text { direct practice }\end{array}$} & $\begin{array}{l}\text { This study aims to find the activity of teachers and children as well as the result of } \\
\text { fine motor development of children in expressing themselves through the detail } \\
\text { drawing movement by applying demonstration model combined with example non- } \\
\text { example model and direct practice method. This study used qualitative approach and } \\
\text { classroom action research (car) with qualitative and quantitative analysis method that } \\
\text { was conducted by three times, the research subject was teachers and children, and the } \\
\text { data was collected through observation and interview. This research consisted of the } \\
\text { following steps: planning, implementation, observation, and reflection. This research } \\
\text { was. The results show that the fine motor development of children increase after the } \\
\text { observation was conducted on teachers who implement learning and in children who } \\
\text { follow the learning drawing in detail. }\end{array}$ \\
\hline & $\begin{array}{l}\text { (c) } 2017 \text { The Authors. Journal of K6, Education, and Management (j-K6EM). ISSN: } 2580-2135 . \\
\text { Published by Graduated Program of Educational Management, Universitas Lambung } \\
\text { Mangkurat, Banjarmasin, Indonesia. This is an open access article under the open journal } \\
\text { systems } 3 \text {. }\end{array}$ \\
\hline
\end{tabular}

*Author correspondence: Sri Rezeki Amalia; E-mail: srirezekiamalia29@gmail.com 


\section{Introduction}

Early childhood is one of important periods in human life. At this period, basic development of human is built. In addition, growth and development are occurred rapidly in this period.

In this rapid globalization era that bring great impacts on human life in a country, education plays an important role in preparing human resources quality. A country will never advance if the human resources have low quality. It is important to notice that science, technology and innovation will continue to develop over time. Consequently, human resources who can think creatively and critically so that the challenges faced can be solved are required. Therefore, the challenges faced today cannot be underestimated. Therefore, we need to examine and address this issue wisely. One of the ways is to prepare a reliable and qualified human resource (HR). The human resource in Indonesia also must be able to think creatively and critically in order to support the quality of education so as not to fall under the negative effects of globalization.

Teaching and learning activities cannot be separated from the role of teachers and learners as the most important component. Teachers are also often said to be at the cutting edge of education. Teachers are one of the most decisive factors in implementing a classroom learning strategy. According to Mulyasa (2015), to be creative, professional and fun teachers, they are required to have the ability to develop an approach and choose effective learning methods.

One of ways to develop fine motor particularly in using a group of muscles such as fingers and hands is through self-expression activities like drawing. Expressing yourself through drawing in detail means the expression of feeling at that moment that is manifested in picture. Since drawing is one of the favorite activities of children, children express their feelings by scribbling whenever and wherever, whether on paper, wall, shirt, or body (Murshid, 2015).

There are still many children who have difficulty in developing their fine motor skill in terms of moving the hand muscles while drawing in detail. The low fine motor development of children resulting in low learning outcomes. This occurs due to teacher-centered education, where the teacher has not accustomed to use the learning model yet. Consequently, the learning given is less attractive and makes children less actively involved and less focused in studying. If the children do not master the motor skill, they are likely to feel discouraged, timid, and selfdoubting, which will eventually result in poor social and personal adaptation. A child who has good motor skills will have more confidence.

This fact can be seen from the presentation of child learning outcomes in Aussyyah Bustanul Athfal Kindergarten 20, Banjarmasin in recent years for the category of self-expression through detailed drawing movement in the field. The researchers found that in 2013-2014, there were 5 children develop, in 2014-2015 there were 6 children develop, and in 2015-2016 there were 6 children develop based on the result of research on developing fine motor aspect by drawing in detail.

From the research problem above, the researchers will involve children during the learning and choose the appropriate model and method. This research aims to assist children in receiving, obtaining and achieving good learning objectives. Therefore, the researchers will use demonstration model combined with example non-example model and direct practice method to solve learning problem occurred in B2 group, Aisyiyah Bustanul Atfhal Kindergaten 20 Banjarmasin.

The methods above were used to form habit, increase the accuracy and speed of learning implementation. These methods also work as a training for children in developing fine motor skill specifically in drawing.

From the background, the researchers would like to conduct a research and find the right model and method, so that the problems in fine motor development can be solved.

This study aims to find the activities of teachers and children, and the results of fine motor development of children in expressing themselves through the drawing movement in detail. We used demonstration model combined with example non-example model and direct practice method. 


\section{Methodology}

A good methodology should bring the researcher to achieve of the objective (Dalle, 2010; Dalle et al., 2017; Derlina et al., 2018). Classroom action research is included as qualitative research even though the data collected may be quantitative in nature. Here, the explanation is in the form of descriptive words, research is the main instrument in data collection, and the process is as important as the product. The researchers focus to understand how an event or effect from an action takes place (Kunandar, 2013).

Classroom action research is a research conducted by teachers in their own class through selfreflection aiming to improve their performance, so that the learning process can run well, and student learning outcomes increase (Uno \& Nurdin, 2012).

According to Arikunto (2015), classroom action research consists of a series of four activities as planning, action, observation, evaluation, and reflection. These activities work to find what is lacking on the implementation that has been done. The results of reflection are used to make improvements to the plan in the next stage.

This classroom action research was conducted in Aisyiyah Bustanul Athfal Kindergarten 20, Banjarmasin with 15 students of B2 group in the academic year 2016-2017, consisting of 4 boys and II girls as the research subject.

Data collection was conducted through interview, observation, and documentation during the learning process in each meeting. Data analysis used in this research was qualitative and quantitative data.

Teacher activity is declared successful if teachers can manage learning with at least good or very good criteria. Assessing the teacher ability could be conducted of observation assessment on each activity. Child activity could be said successful when the child can develop fine motor skill by expressing themselves through drawing in detail and at least it should achieve active or highly active criteria. Development results could be said successful when the child is able to express themselves through drawing in detail, and at least it should achieve minimum criteria by getting

$\star \star \star$ stars if the children develop as expected or $\star \star \star \star$ if the children develop very well.

\section{Results and Discussion}

Based on the results of data, it was found that the learning process by implementing a demonstration model combined with example non-example model and direct practice method can increase teacher and child activities. In addition, the method and model also show the results of fine motor skill development of children in expressing themselves by drawing in detail.

In this stage we created daily activity plan in accordance with the theme and sub-theme, made and prepared tools and materials media to be used for learning activities. We also prepared the rubric of teacher activity, child activity and fine motor development result. And last, we prepared sheets for teacher observation, child observation and fine motor development results.

The learning activities were carried out in accordance with the planning made in $\mathrm{RKH}$ using demonstration model combined with example non-example model and direct practice method. These activities consisted of several stages. I) teacher prepared materials or tools and drawings according to the learning objectives. 2) teacher conveyed the competence to be achieved. 3 ) teacher demonstrated in front of the children. 4) teacher put a picture on the blackboard. 5) teacher gave the children the opportunity in groups to analyze the picture. 6) teachers asked the children in group to tell their work result. 7) teacher asked the children to practice what the teacher had been practiced. 8) teachers and students made conclusions.

The observation results showed that in Meeting I, teachers obtained score 2I with Good category and at Meeting 2 increased to 25 with Good category. Furthermore, at Meeting 3, the teacher activity increased to $3 \mathrm{I}$ with Very Good category.

Teacher activity results during the learning activities from meeting I obtained a value of $57.08 \%$, hat was categorized as Quite Active. In meeting 2 , the obtained value was $68.75 \%$ that was categorized as Active category, and it increased in Meeting 3 by $84.58 \%$, that was categorized as Highly Active category.

Furthermore, on the result of child development in Meeting I, it obtained the value of $33.33 \%$ that was categorized as Undeveloped. At Meeting 
2 , it obtained the value of $73.33 \%$ that was categorized as Develop as According to Expectation. Then, it increased at Meeting 3 by obtaining the value of $93.33 \%$ that was categorized as Very Good category.

In every meeting, the percentage increase as the teachers were able to master the class and understand the activities involving fine motor skill. Here, the children were able to practice fine motor skill such as finger painting and telling the difference between 2 objects (water in a tall thin and low round glass) at Meeting I. At Meeting 2, they drew with crayon and blew the balloon (then released it), and at Meeting 3 they did finger painting. From these activities, it can be understood that the activities in learning also must be in accordance with the understanding and activeness of children.

Teacher activities at meeting I until meeting 3 had increased and had been performed well with very good criteria. These activities also have met the predetermined success indicators. This occurred as the teachers always try to make improvements to the lack in each learning process to produce quality learning.

The child activities from meeting I up to meeting 3 had achieved predetermined success indicators with very active criteria. The children were able to pay attention to the teacher's explanation and dared to ask during the learning process. They worked together and dared to express their opinion during the learning process.

The results of fine motor development from meeting $I$ to meeting 3 show improvement and predetermined success indicators achieved. This is because the children had been able to master the learning that had been given.

Based on these results, all aspects studied, ranging from teacher activity, child activity, and development results tend to increase at each meeting. It shows that the learning quality of the teacher are getting better. In addition, the activities undertaken by teachers during learning can make children become more active in the learning process. The increase and improvement in every meeting help to improve child learning outcomes. So, it can be concluded that there is a correlation between teacher activity, child activity and learning outcomes. In this case, the increased activity of teachers, children become more active and therefore produce better learning outcome.

One of the teacher tasks is giving motivation to their students to carry out their duties in the best possible way, effectively and productively. Teachers play an important role in the learning process. A teacher must be able to master the learning environment well, so that learning does not only focus on what is conveyed by teachers but also on the child activities. Moreover, the students are still in development stage so that they require guidance and assistance from adults (Sanjaya, 2006).

When compared with a research conducted by Karyulina (2015), entitled "Efforts to Develop Cognitive Aspects in Expressing Something in accordance with Individual Work Through Model Demonstration with Discovery Method in Group A at Harapan Kindergarten, Binuang Sub District, Tapin District, it can be seen that teacher activity at every meeting has improved from cycle I to cycle II with score of 33 in very good criteria. Another research conducted by Muliana (20I5) entitled, "Efforts to Develop the Aspect of Religion and Moral Value of Children Through Accustomed Polite Behavior Conducted with Example Non Example Model and Storytelling Method in Group B, Insan Azkia Kindergarten, Banjarmasin, it shows optimal results where the teacher activity at each meeting improve from cycle I to cycle II so score of 35 with very good criteria is obtained.

A counselor or teacher should have some of the following characteristics including patient, affectionate, caring, friendly, tolerant, empathetic, loving, warm, child-friendly, fair, as well giving children freedom and creating familiarity with children (Susanto, 2015).

Teachers or educational planners should prepare whatever material they wish to convey, how to convey and what media is used beforehand. In relation to this matter, every teacher should be competent in explaining generally in accordance with the topic/subject matter learned by the children (Sujiono, 20I2).

Teacher is a component that determines the success of a lesson, since a teacher is a person who directly faces the child. In learning system, teacher can work as a planner or designer in learning. As a planner, teachers are required to 
understand correctly the applicable curriculum, characteristics of children, as well as facilities and resources in preparing lesson plan. The role and activity of a teacher is very important in the learning as effectiveness and efficiency of individual learning in school is highly dependent on the teacher role. Teachers should always try to facilitate or create condition so that the learners can learn actively due to their own will.

When viewed from the results of research by using three combinations, the teacher achievement increased at meeting 3 with the score of $3 \mathrm{I}$ in very good criteria and this is in line with the expert opinion as follows. In optimizing the process of kindergartener development to the right and conducive direction, kindergarten teacher has an important and strategic role in children development. For that reason, teachers cannot teach in kindergarten with one or two methods/strategies alone, but they need to have creativity to create variation of learning activity strategy (Suriansyah \& Aslamiah, 20II).

One of the characteristics of children is to have great curiosity. Children in early childhood pay attention, talk and ask things that have been seen and heard, particularly about new things (Masitoh, 20I4). The new things that will be seen, heard and done will form the habit in children during their growth and development. From the result of Setianingsing (2015) research entitled, "Improving Learning Outcome on Earth and Sky Object Appearance Material through the Combination of Demonstration and Numbered Head Together (NHT) Model on 4th Grade Students at Java Elementary School 3 Martapura" shows increase from $58 \%$ in cycle I to $83 \%$ in cycle II. In line with Djamarah (20II) opinion, interest is a tendency to pay attention and remember various activities. A person who is interested in an activity will pay attention to this activity consistently and happily.

Child characteristic is active and energetic. Children typically love to engage in an activity, especially when faced with new and challenging activities. For children, activity is a pleasure. Children are explorative, adventurous as they are pushed by a great curiosity about something. Children want to try and learn new things. Basically, children can build and create their own knowledge, so it is important to be directly involved in the learning process (Masitoh, 20I4).
Piaget also explains that most children learning experience are gained by playing, experimenting with real objects and going through concrete experience. Children could create and manipulate objects or ideas (Sujiono, 20I2). On the research by Hendriati (2012) entitled, "Efforts to Improve Fine Motor and Physical Development on Visual Art Aspect by Example Non-Example Model in Group B students of Al-aman Islamic Kindergarten, Banjarmasin, it showed that mastery in cycle I was $36.00 \%$ and increased to $88.90 \%$ in cycle II. So, it can be said that every development will success if it is performed according to the children potential and if the solution to the problem faced by child is given.

Encouraging learners to speak up and express their opinions to improve child activities in following the lesson is important in the development of learning process that is participatory, active, innovative, creative, effective and fun (Suprijono, 2009).

Let's take an example. In a game, there are rules that must be obeyed and implemented. Kindergarteners need more praise and appreciation as well as solution on how to play game properly and correctly. Playing game trains, the independence of children in doing things by not relying on others and train the discipline of children. Children are more enthusiastic in learning, because the instinct of children at an early age says that learning is playing (Sanjaya, 2007).

Confidence is very important as a child with confidence will be optimistic in doing all activities and has a realistic goal. It means that an individual will make life goals that are able to be achieved, so what is planned will be done with confidence and it will succeed. This is in accordance with Pratisiti (2007) opinion who said that by having confidence, someone can do anything with the belief that it will succeed, if it fails, someone does not necessarily fall into despair, but still have the spirit, be realistic and then trying again steadily.

As the teachers choose and determine the accuracy in learning by using the demonstration model combined with example non-example model and direct practice method, fine motor development of children increase. During the activities, teachers provide guidance, direction and motivation to children so that the optimal child 
development outcomes are obtained. Dimiyati (2002) also said that learning outcome is usually shown by the score of tests given by teachers. While according to Jenkin, learning outcome is a statement showing what students might do as a result of their learning activities. So, learning outcome is the form of certain abilities (Uno \& Nurdin, 20II).

According to Gadne in Sumarno (20II), learning outcome is the internal capability that includes knowledge, skill and attitude that have become a private property of someone who allows his/her to do something (Hazizah, 20I4). Child learning outcomes are shown on the mastery level of competencies and learning experiences learned during the teaching and learning process. With the evaluation of learning outcomes, we can determine whether we should continue learning to the next level or repeat the lesson (Djamarah, 20II).

The development of child fine motor skills will be successful when the learning process is fun. It is supported by Idris (20I4) who said that "a fun teacher will be able to raise the spirit of student in learning by delivering the subject matter interestingly and impressively, so that students are happy and not forced in receive lessons". With a fun learning atmosphere then the learning objectives will be easily achieved.

David in Masitoh (20I4), a child-oriented learning development, the kindergarten teachers must understand the needs and characteristics of child development. This type of learning gives children more opportunity to learn in the right ways.

From the several researches presented above and with the theoretical results obtained from the experts, the research results show that the activity of teacher and children, as well as the learning outcomes of children increase. When compared with previous studies that employed one or two solutions, this research obtained better result by using three combination of demonstration model, example non-example model, and direct practice method.

\section{Conclussion and Recomendations}

Based on the results of action research, reflection and discussion at meeting $\mathrm{I}, 2$, and 3 , it can be concluded that the learning outcomes of children increase after the improvement of the teacher and child activities in learning. Based on results, the recommendations are First, teachers shall use the proper learning model and method as an alternative to increase the child learning outcomes. By using the right model and method, it can create a fun learning process, improve the spirit and cooperation of children, make the children to be more active optimally, and create a more meaningful learning; Second, the principal shall encourage and motivate the teachers to apply a good learning model and method, as it can help to improve the process and increase the learning outcomes in B2 group of Aisyiyah Bustanul Athfal Kindergaten 20, Banjarmasin; Third, this research works as a material for the next researchers to improve the research quality. In addition, with this research we hope that the next researchers pay more attention to efficient time allocation so that the implementation can run optimally.

\section{Acknowledgment}

No acknowledgment

\section{References}

Arikunto, S. (20I5). Penelitian tindakan kelas. Jakarta: BumiAksara.

Dalle, J. (2010). Metodologi umum penyelidikan reka bentuk bertokok penilaian dalaman dan luaran: Kajian kes sistem pendaftaran siswa Indonesia. Thesis PhD Universiti Utara Malaysia.

Dalle, J., Hadi, S., Baharuddin., \& Hayati, N. (2017). The Development of Interactive Multimedia Learning Pyramid and Prism for Junior High School Using Macromedia Authorware. The Turkish Online Journal of Educational Technology, November. 7I4-72I.

Derlina., Dalle, J., Hadi, S., Mutalib, A.A., \& Sumantri, C. (2018). Signaling Principles in Interactive Learning Media through Expert's Walkthrough. Turkish Online Journal of Distance Education (TOJDE). I9(4), I47-I62

Djamarah, S.B. (20II). Psikologi belajar. Jakarta: Rineka Cipta.

Kunandar. (2013). Langkah mudah penelitian tindakan kelas sebagai pengembangan profesi guru. Jakarta: Raja Grafindo Persada.

Masitoh, (20I4). Strategi pembelajaran tk. Jakarta: Universitas Terbuka. 
Mulyasa. (2015). Manajemen paud. Bandung: Rosdakarya Offset.

Murshid. (2015). Belajar dan pembelajaran paud. Bandung: Remaja Rosdakayra Offset.

Sanjaya, W. (2006). Perencanaan dan desain sistem pembelajaran. Jakarta: Kencana.

Sanjaya, W. (2007). Strategi pembelajaran berorientasi standar proses pendidikan. Jakarta: Kencana Prenada Media Group.

Sujiono, Y.N. (2012). Konsep dasar pendidikan anak usia dini. Jakarta: PT Indeks.

Suriansyah, A., \& Aslamiah, (201I), Strategi pembelajaran anak usia dini. Banjarmasin: Comdes.

Susanto, A. (2015). Bimbingan \& konseling di $t$. Jakarta: Kencana.

Uno, H.B., \& Nurdin, M. (2015). Belajar dengan pendekatan pailkem. Jakarta: Bumi Aksara. 
ISSN 2580-2135 